\title{
Proteolytic activity in coastal oceanic waters: depth distribution and relationship to bacterial populations
}

\author{
Abbey L. Rosso*, Farooq Azam \\ Institute of Marine Resources, A-018, Scripps Institution of Oceanography, University of California, San Diego, La Jolla, \\ California 92093, USA
}

\begin{abstract}
Proteolytic activity and the role of bacteria in protein degradation in seawater were investigated during 2 cruises to the Santa Monica Basin. The rate of hydrolysis of L-leucyl- $\beta$-naphthylamine was used as a measure of proteolytic activity, and was compared with bacterial numbers, production, and growth rates throughout the water column (905 $\mathrm{m}$ max. depth). Peak proteolytic activities in the upper $100 \mathrm{~m}$ of the water column were more than 10 times those of deeper waters, though the natural substrate concentrations (combined hydrolyzable amino acids) in the Santa Monica Basin have previously been found to vary by only 3 to 4 -fold. Sediment porewaters were assayed during one cruise and found to have 20 to 30 times more proteolytic activity than the peak water column samples from the same cruise, though the origin of this activity could not be determined. Most of the proteolytic activity in the water column was associated with particles the size of bacteria $(0.2$ to $0.8 \mu \mathrm{m})$ and, overall, total proteolytic activity was highly correlated with all bacterial variables tested. However, the average activities per cell were not related to average cell sizes, suggesting that proteolytic activity is not simply a function of bacterial biomass. In samples from one of the cruises, the average activities per cell covaried with bacterial growth rates (thymidine incorporation per cell), but this was not true for samples taken during the second cruise. Laboratory experiments using 'seawater cultures' indicated that neither changes in cell size nor growth rate alone could account for changes in the amount of proteolytic enzyme expressed by marine bacteria. These results suggest that proteolytic activity in the water column is primarily associated with bacteria and is likely to be controlled by a number of factors related to the bacterioplankton, including biomass and growth rates.
\end{abstract}

\section{INTRODUCTION}

Dissolved proteins and peptides may be an important source of energy and nitrogen for marine bacteria (Azam \& Ammerman 1984b, Billen 1984, Wheeler \& Kirchman 1986). They constitute a significant fraction of the total dissolved organic nitrogen (DON) in the ocean, and represent one of the largest identified pools of DON (Sharp 1983, Billen 1984, Williams 1986). However, proteins and peptides must be hydrolyzed to amino acids or oligopeptides before uptake by bacteria (Law 1980). Thus, knowledge of how proteolytic activity is controlled is important to our understanding of bacterial utilization of proteins in the sea.

In recent years, following the development of

\footnotetext{
- Corresponding author; present address: PO Box 163. Bodega Bay, California 94923, USA
}

methods sensitive enough for seawater samples, it has been shown that proteolytic activity is largely associated with bacteria, rather than dissolved in seawater (Hollibaugh \& Azam 1983, Somville \& Billen 1983). It is thought that marine bacteria have proteases bound to their outer envelopes (Hollibaugh \& Azam 1983, Vives Rego et al. 1985, Rosso unpubl.), and that product (amino acid) uptake is tightly coupled to proteolysis (Amano et al. 1982, Hollibaugh \& Azam 1983). Thus, some regulation of protease production by marine bacteria might be expected, with possible controlling factors being the availability of proteins and/or the bacterial population's need for hydrolysis products.

The nature of regulation of bacterial proteolytic activity in the ocean is not clear, however. Fontigny et al. (unpubl.) have shown that species selection as well as enzyme production can affect the total proteolytic activity of a mixed population of marine bacteria, but in 
natural samples they found that such activity can generally be considered a function of bacterial biomass. On the other hand, Vives Rego et al. (1985) found that, in coastal and estuarine waters, the size distribution of proteolytic activity follows more closely the distribution patterns of bacterial growth than bacterial numbers. Although they suggest this may be because bigger bacteria or bacteria attached to particles have more protease activity, it may also imply a relationship between bacterial growth and the expression of proteolytic enzymes. Hoppe (1983) has suggested that more 'active' bacteria may have greater protease activity. It should be noted, however, that proteolytic activity has also been shown to correlate well with a number of other variables, including chlorophyll $a$, primary productivity, amino acid turnover rates, particulate organic nitrogen and dissolved organic carbon (Hollibaugh \& Azam 1983, Hashimoto et al. 1985).

Here we report results of a study of the role of bacteria in determining rates of protein hydrolysis in seawater. Measurements were taken throughout the water column ( $905 \mathrm{~m}$ max. depth) at 2 different times of the year to look for correlations between proteolytic activity and bacterial abundance, biomass, production, and growth rates. Causal relationships were then studied in a laboratory experimental system wherein natural assemblages of bacteria were grown in filtersterilized, unenriched seawater ('seawater culture'; Ammerman et al. 1984).

\section{MATERIALS AND METHODS}

Sampling. Water samples were taken from over the shelf, slope and bottom of the Santa Monica Basin (SMB), USA, at Southern California Bight Study stations 303, 304, and 305 (region described by Eppley et al. 1978, Carlucci et al. 1986) during 2 cruises aboard RV New Horizon (13 to 17 Oct 1985 and 16 to 20 May 1986). Sampling locations are listed in Table 1. During the fall cruise (October 1985), 3 profiles were taken over $4 \mathrm{~d}$, each by repeatedly lowering a single $5 \mathrm{l}$ Niskin bottle which was washed with $2 \mathrm{~N} \mathrm{HCl}$ between uses; 2 of the profiles were taken over the central basin (Profiles 1 and 2), at approximately Stn 305; the third was from over the slope, at about Stn 304 (Profile 3). Samples from the spring cruise (May 1986) were selected from among 7 bottle casts taken over 3 d at Stn 305 and Stn 303, which is over the shelf; Niskin bottles were acid-washed once a day. All samples from the euphotic zone were taken in mid to late afternoon, with the exception of the $27 \mathrm{~m}$ sample from the spring cruise, which was from an early morning bottle cast; exact sampling locations are listed in Table 1. Samples from the Scripps Institution of Oceanography (SIO) pier $\left(32^{\circ} 53^{\prime} \mathrm{N}, 117^{\circ} 15^{\prime} \mathrm{W}\right)$ were collected by lowering a weighted, polypropylene Erlenmeyer flask, which had been acid-washed and autoclaved, from the end of the pier to just below the water's surface.

Sediments from the central basin and slope station (approx. Stns 305 and 304; Table 1) were sampled during the fall cruise with a Soutar box corer. Subcores were taken and sectioned as described by Jahnke et al. (1986), except that the overlying water was removed by pipet before sectioning and saved. Porewater was obtained by centrifuging the sediment samples for $1 \mathrm{~min}$ in an Eppendorf microfuge at $4^{\circ} \mathrm{C}$. The porewater removed from above the sediment pellet after centrifuging was diluted 4 to 5 times with the autoclaved seawater used for blanks (see below) before assaying for protease activity.

Seawater cultures (SWCs) were started as described by Ammerman et al. (1984). Natural assemblages of bacteria present in $0.6 \mu \mathrm{m}$ filtrates (Nuclepore filters) of seawater from the SIO pier were used to inoculate $(10 \% \mathrm{v} / \mathrm{v})$ filter-sterilized seawater (Nuclepore filter. $0.2 \mu \mathrm{m})$.

Measurement of proteolytic activity. Hydrolysis of fluorogenic L-leucyl- $\beta$-naphthylamide (LL $\beta N_{i}$ ICN Pharmaceuticals, Inc.) was used to measure proteolytic activity (Somville \& Billen 1983). Substrate was added to water column samples in sterile $10 \mathrm{ml}$ polystyrene tubes, with replicates representing multiple tubes per sample; time points were taken by removing subsamples to a quartz cuvette for measurement of fluorescence. Porewater samples were both incubated and

Table 1. Santa Monica Basin sampling locations and dates. See 'Materials and Methods' for explanation of station numbers

\begin{tabular}{|c|c|c|}
\hline Sample & Date & Location \\
\hline \multicolumn{3}{|l|}{ Fall 1985} \\
\hline \multicolumn{3}{|l|}{ Stn 304 (slope) } \\
\hline Profile 3 & 16 Oct & $33^{\circ} 51^{\prime} \mathrm{N} 118^{\prime} 38^{\prime} \mathrm{W}$ \\
\hline Boxcore 2 & 16 Oct & $33^{\circ} 51^{\prime} \mathrm{N} 118^{\prime} 39^{\prime} \mathrm{W}$ \\
\hline \multicolumn{3}{|l|}{ Stn 305 (basin) } \\
\hline Profile 1 & 13 Oct & $33^{\circ} 46^{\prime} \mathrm{N} 118^{\circ} 48^{\prime} \mathrm{W}$ \\
\hline Profile 2 & $13 \mathrm{Oct}$ & $33^{\circ} 42^{\prime} \mathrm{N} 118^{\prime} 54^{\prime} \mathrm{W}$ \\
\hline Boxcore 1 & 14 Oct & $33.42 \mathrm{~N} 118^{\circ} 56^{\prime} \mathrm{W}$ \\
\hline \multicolumn{3}{|l|}{ Spring 1986} \\
\hline $\begin{array}{r}\text { Stn } 303 \text { (shelf) } \\
(9,23,33 \mathrm{~m})\end{array}$ & 18 May & $33^{\circ} 53^{\prime} \mathrm{N} 118.31^{\circ} \mathrm{W}$ \\
\hline \multicolumn{3}{|l|}{ Stn 305 (basin) } \\
\hline $27 \mathrm{~m}$ & $17 \mathrm{May}$ & $33^{\circ} 46^{\prime} \mathrm{N} 118^{\circ} 48^{\circ} \mathrm{W}$ \\
\hline $10.100 \mathrm{~m}$ & 19 May & $3345^{\prime} \mathrm{N} 118^{\circ} 51^{\prime} \mathrm{W}$ \\
\hline $500 \mathrm{~m}$ & 18 May & $33.44^{\prime} \mathrm{N} 118^{\circ} 50^{\circ} \mathrm{W}$ \\
\hline $500 \mathrm{~m}$ & $19 \mathrm{May}$ & $3342 \mathrm{~N} 11853^{\circ} \mathrm{W}$ \\
\hline $700 \mathrm{~m}$ & $17 \mathrm{MaY}$ & $33^{\circ} 45^{\circ} \mathrm{N} 118^{\circ} 48^{\circ} \mathrm{W}$ \\
\hline $905 \mathrm{~m}$ & 17 May & $33.45^{\prime} \mathrm{N} 118.52^{\prime} \mathrm{W}$ \\
\hline
\end{tabular}


assayed for fluorescence in disposable cuvettes due to the small sample volumes. All incubations were done in the dark, though laboratory light did not seem to affect the assay. Fluorescence was measured with $340 \mathrm{~nm}$ excitation and $410 \mathrm{~nm}$ emission using a Farrand spectrofluorometer (system 3 model), and calibrated with $\beta$ naphthylamine ( $\beta \mathrm{N}$; Sigma Chemical Co.) in seawater.

For most assays, the initial concentration of LL $\beta N$ was $1 \mathrm{mM}$, as this concentration was saturating in pier seawater, and was also the concentration previously reported to be saturating in other coastal waters (Somville \& Billen 1983). Because most assays were also done at a single temperature $\left(15^{\circ} \mathrm{C}\right)$, the rates represent a measure of the relative quantities of enzyme present, or total proteolytic activity, rather than relative in situ rates. During the spring cruise, representative surface and deep water samples were also assayed at varying substrate concentrations and temperatures in order to test whether the enzymes in our samples differed in their kinetic properties from those of previously tested waters, and to determine the effect of temperature on hydrolysis rates. Knowledge of the effect of temperature on the rates allowed for the comparison of a few deep samples, which had been assayed only at in situ temperatures, with those assayed at $15^{\circ} \mathrm{C}$.

During the fall cruise, assays were run in duplicate with 2 or 3 time points taken over the course of $4 \mathrm{~h}$ or less. The spring cruise samples and blanks were run in

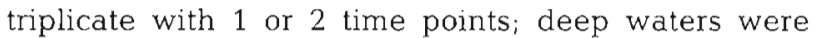
incubated for up to $6 \mathrm{~h}$, and euphotic zone water was assayed over a 2 to $3 \mathrm{~h}$ period. SWC assays were run in triplicate with 1 or 2 time points in $\leq 30 \mathrm{~min}$. For size fractionations, aliquots were filtered through Nuclepore filters using moderate vaccum $(<25 \mathrm{~cm} \mathrm{Hg})$ before addition of substrate. Bacterial concentrates were made by incompletely filtering a relatively large water sample ( 7 to 10 times final volume) through a $0.2 \mu \mathrm{m}$ Nuclepore filter and then removing the unfiltered, particle-enriched portion from above the filter.

Blanks during the fall cruise consisted of autoclaved filtered seawater, which was refiltered through $0.2 \mu \mathrm{m}$ Nuclepore filters just before use to remove any particles formed upon autoclaving. Changes in the blanks were always negative, with the decreases in initial fluorescence occurring more rapidly at the beginning of incubation periods. This may be due to the adsorption of substrate or contaminating $\beta N$ to container walls or particles. In all subsequent assays, boiled sample water (10 min in a boiling water bath) was used for blanks in order to better approximate losses in fluorescence due to adsorption and/or quenching.

LI. $\beta N$ hydrolysis rates were calculated by subtracting the average change in fluorescence of the blanks from the average change in fluorescence of the samples at each time point. The net changes in fluorescence at each time point were then used to determine the slope of the line of best fit through all points. Time courses from the fall cruise were linear ( $r>0.95$ and usually $\geq 0.99$ ) when activities were greater than about 0.072 units (with 1 unit defined as 1 nmole $\beta \mathrm{N}$ produced $1^{-1}$ min $^{-1}$ ); duplicates of these samples varied by $<25 \%$ of their means, and most varied by $<15 \%$, with the exception of the replicates from $900 \mathrm{~m}$ and a few of the sediment samples which had ranges of up to $75 \%$. Samples with low activity $(<0.072$ units) had net fluorescence changes that were often negative at early time points, becoming more positive with time. Some of the ranges of activity in these samples were as low as $10 \%$ of the mean; others were as high as $200 \%$, but this represents a relatively small absolute error in these low activity samples.

Time courses of low activity samples from the spring cruise were more often linear owing to the change of method for determining blanks (see above). However, significant and sometimes linear 'negative activity', a net decrease in fluorescence, was frequently recorded (changes in fluorescence of the samples were significantly more negative than those of the blanks by Students t-test at $\mathrm{p}<0.05$ ). The negative activities were small, but made direct quantitative comparisons of activities difficult. We do not, at present, know what causes the apparent negative activities (see kinetics results). However, when representative low activity waters were concentrated before assaying (this procedure is not expected to cause significant bacterial cell damage or lysis; see above for methodology), their apparent activities increased to well above the blank rates. Thus, although it was difficult to quantitate in some cases, there did seem to be measurable activity in all waters assayed. Coefficients of variation (CVs) for assays done in the spring were $<9 \%$ for whole water and $0.8 \mu \mathrm{m}$ filtrates from $\leq 100 \mathrm{~m}$, and for SWCs; $0.2 \mu \mathrm{m}$ filtrates and samples from $>100 \mathrm{~m}$ had CVs of 15 to $100 \%$.

Bacterial abundance and biovolume. Water samples preserved with borate-buffered formalin $(3 \%$ final conc., v/v) were used for the enumeration of bacteria by epifluorescence microscopy after staining with acridine orange (AODC; Hobbie et al. 1977). Final counts represent the averages of 3 filters (subsamples) for field samples, with 10 fields of 20 or more bacteria counted on each filter; CVs of replicate filters were all under $27 \%$ and most were under $9 \%$. SWC samples were counted on duplicate filters.

Cell sizes were determined by projecting the negatives from photomicrographs of representative fields from the AODC slides and measuring individual cell dimensions. Final magnification was determined from the projection of a micrometer photomicrograph 
and was usually about $8400 \times$. Forty to 60 cells, usually from 2 photographs, were measured for each sample and volumes were calculated as: $\pi r^{2}[L-2 / 3 r]$ (cylinders with hemispherical caps, the equation becomes $4 / 3 \pi r^{3}$ when cells are spheres; Fuhrman 1981). The standard errors of the volume measurements of representative, average sized cells were from 3 to $9 \%$ of the mean when measured 3 times, and standard errors of the mean volumes of all cells in a sample (each cell measured once) were 10 to $12 \%$ of the sample mean.

Bacterial production and growth rates. Bacterial production was determined by measuring incorporation of ${ }^{3} \mathrm{H}$-thymidine $\left({ }^{3} \mathrm{H}-\mathrm{Tdr} ; 75\right.$ to $85 \mathrm{Ci} \mathrm{mmol}{ }^{-1}$; New England Nuclear; $10 \mathrm{nM}$ final conc.) as described by Fuhrman \& Azam (1982), with samples incubated at near in situ temperatures (Tables $2 \& 3$ ). During the fall cruise, incorporation into the cold TCA precipitable fraction was measured, with samples and blanks (formalin-killed) run in duplicate; $2 \mathrm{~h}$ incubations were used, with $10 \mathrm{ml}$ per replicate in the upper waters and $50 \mathrm{ml}$ per replicate for samples from $\leq 200 \mathrm{~m}$. Production measurements from the spring cruise are from B. C. Cho \& F. Azam (unpubl; $905 \mathrm{~m}$ sample not assayed). For SWCs, 1 h incubations of triplicate samples and blanks were used, and incorporation into DNA was determined, as the percent incorporated into DNA was found to vary depending on the stage of the culture. Growth rates were approximated by dividing the ${ }^{3} \mathrm{H}$-Tdr incorporation rate by the number of bacteria present.

Table 2. Incubation temperatures used for ${ }^{3} \mathrm{H}-\mathrm{Tdr}$ incorporation experiments during fall 1985 cruise (approxiamate in situ temperatures)

\begin{tabular}{|ccc|}
\hline Stn & Depth $(\mathrm{m})$ & $\begin{array}{c}\text { 3H-Tdr } \\
\text { Incub. temp }\left({ }^{\circ} \mathrm{C}\right)\end{array}$ \\
303 & 0 & 20 \\
& 18 & 14 \\
& 40 & 11 \\
& 100 & 11 \\
& 250 & 9 \\
395 & 9 \\
& 0 & 20 \\
& 108 & 18 \\
40 & 13 \\
100 & 11 \\
300 & 7 \\
500 & 7 \\
700 & 5 \\
900 & 5 \\
\hline
\end{tabular}

\section{RESULTS}

\section{Proteolytic activity in the water column}

Proteolytic activity varied greatly with depth during the fall cruise (Fig. 1). Peak values were similar among stations ( 0.58 to $0.88 \mathrm{nmol} L L \beta N$ hydrolyzed $l^{-1} \mathrm{~min}^{-1}$ ) and in all cases they were found at $40 \mathrm{~m}$, corresponding approximately with the depth of the chlorophyll maximum measured in the same waters within a few days of

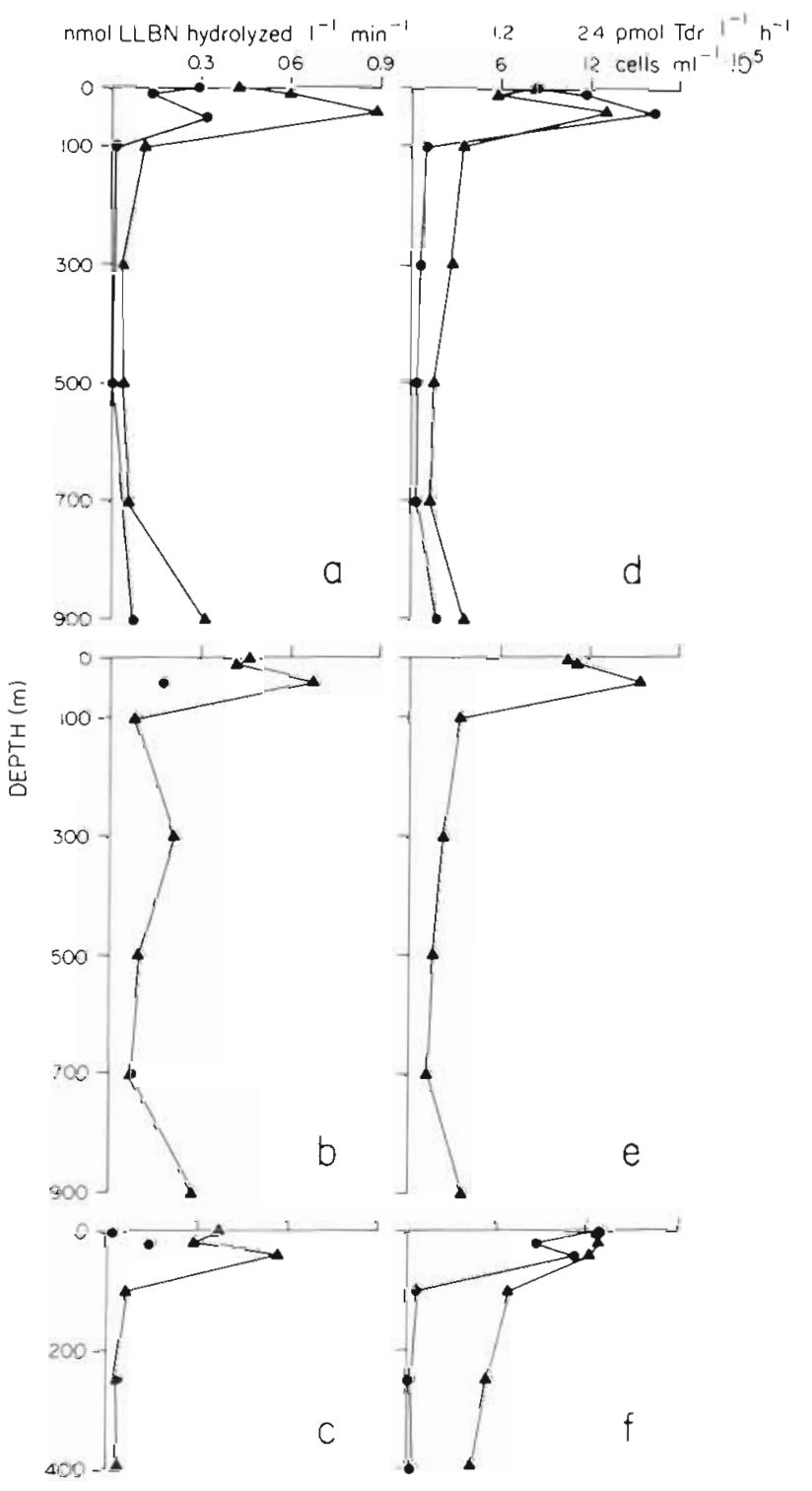

Fig. 1 Depth distributions. (a-c) Total ( 4 ) and dissolved ( $\bullet$ proteolytic activity (nmol LL $\beta N$ hydrolyzed $\mathrm{l}^{-1} \mathrm{~min}^{-1}$ ); (d-f) bacterial abundance $(\mathbf{\Lambda})$, and thymidine incorporation rates $\left(\mathrm{pmol} \mathrm{Tdr} \mathrm{l}^{-1} \mathrm{~h}^{-1}\right.$ ) ( $\bullet$ ) during fall 1985. (a) and (e) are from Profile 1, Stn 305; (b) and (e) from Profile 2, Stn 305; (c) and (f) from Profile 3, Stn 304 
Table 3. Proteolytic activities (LLBN hydrolysis rates) and other results from the spring 1986 cruise

\begin{tabular}{|c|c|c|c|c|c|}
\hline Stn & $\begin{array}{l}\text { Depth } \\
(\mathrm{m})\end{array}$ & $\begin{array}{l}\text { LLBN hydrol. rate } \\
\left(\mathrm{nmol} \mathrm{l}^{-1} \mathrm{~min}^{-1}\right)\end{array}$ & $\begin{array}{l}\text { Bacteria } \mathrm{ml}^{-1} \\
\left(\times 10^{-5}\right)\end{array}$ & $\begin{array}{l}\text { Thymidine incorp. } \\
\text { rate }\left(\mathrm{pmol} 1^{-1} \mathrm{~h}^{-1}\right)^{\mathrm{d}}\end{array}$ & $\begin{array}{l}\text { Chl } a^{b} \\
\left(\mu g l^{-1}\right)\end{array}$ \\
\hline \multirow{3}{*}{303} & 9 & 3.80 & 34.8 & $30.07\left(15^{\circ} \mathrm{C}\right)$ & 1.049 \\
\hline & 23 & 1.21 & 15.3 & $8.94\left(13^{\circ} \mathrm{C}\right)$ & 1.319 \\
\hline & 33 & 1.00 & 16.1 & $17.00\left(13^{\circ} \mathrm{C}\right)$ & 1.215 \\
\hline \multirow{6}{*}{305} & 10 & 2.06 & 37.3 & $28.11\left(16^{\circ} \mathrm{C}\right)$ & 2.049 \\
\hline & 27 & 1.28 & 20.2 & $8.25(12 \mathrm{C})$ & 1.618 \\
\hline & 100 & 0.349 & 6.8 & $3.78\left(12^{\circ} \mathrm{C}\right)$ & $\mathrm{NA}$ \\
\hline & 500 & 0.025 & 1.7 & $0.05 \quad\left(7^{\circ} \mathrm{C}\right)$ & NA \\
\hline & 700 & 0.023 & 1.3 & $0.12\left(7^{\circ} \mathrm{C}\right)$ & NA \\
\hline & $905^{c}$ & 0.046 & 3.9 & NA & NA \\
\hline \multicolumn{6}{|c|}{$\begin{array}{l}\text { aData from B.C. Cho \& F. Azam unpubl. Incubation temperatures in parenthesis }\left({ }^{\circ} \mathrm{C}\right) \\
{ }^{b} \text { Food Chain Research Group, unpubl. }\end{array}$} \\
\hline
\end{tabular}

our sampling (E. Renger pers. comm.). Below this peak, proteolytic activity decreased sharply (approx. 10×), remaining relatively constant below $100 \mathrm{~m}$ except for an increase in activity seen in the deepest samples from Profiles 1 and 2, which were taken within $5 \mathrm{~m}$ of the bottom. The increased proteolytic activity in the deepest samples was accompanied by slight increases in bacterial concentrations and bacterial production rates, and by increases in the particle loads observed in the microscopy samples. No such increases were observed in Profile 3 over the basin slope, though the deepest sample was taken equally close to the bottom. In general, in profiles from the fall cruise, the distribution of total proteolytic activity parallels bacterial production more closely than cell numbers (see correlations section below)

Table 4. Proteolytic activities in sediment porewaters assayed in fall 1985 (nmol LLBN hydrolyzed $\mathrm{l}^{-1} \mathrm{~min}^{-1}$ )

\begin{tabular}{|c|c|c|c|c|}
\hline $\begin{array}{l}\text { Depth } \\
\text { range } \\
(\mathrm{cm})\end{array}$ & $\begin{array}{l}\text { Size } \\
\text { fraction } \\
\quad(\mu \mathrm{m})\end{array}$ & Subcore A & Subcore B & Core 2 \\
\hline $\begin{array}{l}\text { Overlying } \\
\text { water }\end{array}$ & $\begin{array}{l}\text { Total } \\
<0.2\end{array}$ & $\begin{array}{l}0.22 \\
0.00\end{array}$ & $\begin{array}{c}0.57 \\
-\end{array}$ & $\begin{array}{l}(2.2)^{b} \\
(0.18)^{b}\end{array}$ \\
\hline $0-0.5$ & $\begin{array}{l}\text { Total } \\
<0.2\end{array}$ & $\begin{array}{c}25.2 \\
-\end{array}$ & $\begin{array}{l}23.5 \\
19.3\end{array}$ & $\begin{array}{l}7.0 \\
7.2\end{array}$ \\
\hline $0.5-1.5$ & $\begin{array}{l}\text { Total } \\
<0.2\end{array}$ & $\begin{array}{c}11.2 \\
-\end{array}$ & $\begin{array}{l}14.8 \\
23.5\end{array}$ & $\begin{array}{r}13.5 \\
7.8\end{array}$ \\
\hline $1.5-3.0$ & $\begin{array}{l}\text { Total } \\
<0.2\end{array}$ & $\begin{array}{c}11.2 \\
-\end{array}$ & $\begin{array}{l}13.6 \\
17.5\end{array}$ & $\begin{array}{r}11.5 \\
4.6\end{array}$ \\
\hline \multicolumn{5}{|c|}{$\begin{array}{l}{ }^{\mathrm{a}} \text { Assayed at } 4{ }^{\circ} \mathrm{C} \text { and converted to values expected at } 15^{\circ} \mathrm{C} \\
\text { using a } Q_{10} \text { of } 2.2 \\
{ }^{b} \text { Sediment-water interface had been disturbed }\end{array}$} \\
\hline
\end{tabular}

Depth distribution of proteolytic activity during the spring cruise (Table 3) was similar to that of the fall cruise, except that the activity maximum was much shallower. However, peak activities in the upper waters were greatly increased relative to the fall values and were not always found at the depth of highest recorded chlorophyll a concentrations, which were determined simultaneously. Furthermore, total activities followed cell numbers more closely than bacterial production (see correlations).

\section{Proteolytic activity in sediment porewater}

Porewater sampled on the fall cruise (Table 4) had very high proteolytic activity relative to the water column (up to $30 \times$ greater than the highest water column value from fall). This was true for both boxcores assayed, though they were qualitatively very different. Core 1 , from the central basin, was extremely rich in living biomass (ATP concentrations as high as $17 \mu \mathrm{g} \mathrm{cm}^{-3}$ or $230 \mu \mathrm{g} \mathrm{g}^{-1}$; R. Jahnke unpubl.), with a yellow, presumably bacterial mat on the surface. Proteolytic activity as well as ATP levels were highest at the surface, but, interestingly enough, the overlying water had only about $1 \%$ as much activity as the porewater (approximately equivalent to the activity of the deepest bottle cast samples). Porewaters from the second core, taken on the slope of the basin, had activities somewhat lower, but comparable to those measured in the first core, even though the second core had considerably lower living biomass (about $1 \mu \mathrm{g} \mathrm{cm}^{-3}$ throughout and from about 2.5 to $4 \mu \mathrm{g} \mathrm{g}^{-1}$ ATP; R. Jahnke unpubl.). Peak proteolytic activity was not found at the surface of this core and the overlying water had high activity relative to other 
bottom waters. However, the results from this core may be unrepresentative because the sample site appeared to have recently slumped and the core had also been slightly disturbed during sampling.

\section{Size distribution of proteolytic activity}

In fall, depth distribution of dissolved proteolytic activity $(<0.2 \mu \mathrm{m}$ fraction) in the water column did not parallel that of total activity (Fig. 1). Above about $100 \mathrm{~m}$, generally $<30 \%$ of the proteolytic activity was dissolved both in fall and spring (not shown). The most notable exception to this was at $0 \mathrm{~m}$ in Profile 1 from the fall, where $70 \%$ of the activity was $<0.2 \mu \mathrm{m}$. In the low activity waters below $100 \mathrm{~m}$, it was difficult to determine the percent dissolved due to uncertainty regarding the blanks (see 'Materials and Methods'), but dissolved activity was usually much lower than total proteolytic activity

Particle-associated proteolytic activity was primarily in the bacterial size fraction $(0.2$ to $0.8 \mu \mathrm{m})$. Most fractionation data was collected during the spring cruise (Fig. 2), and the same pattern was found in the fall (data not shown). In spring, approximately 70 to $75 \%$ of the particulate activity (total activity minus activity in $<0.2$ $\mu \mathrm{m}$ filtrate) passed $0.8 \mu \mathrm{m}$ filters at all depths except $100 \mathrm{~m}$. However, almost all of the bacteria passed through $0.8 \mu \mathrm{m}$ filters at all depths (Fig. 2). Most of the bacterial production in the upper $100 \mathrm{~m}$ of the water column during the spring cruise was also due to the 0.2 to $0.8 \mu \mathrm{m}$ fraction ( 95 to $97 \%$ ), though in water from 500 to $700 \mathrm{~m}$, only 40 to $50 \%$ was due to the $0.8 \mu \mathrm{m}$ filterable fraction (B. C. Cho \& F. Azam unpubl.).

In contrast with the water column, sediment porewater had very high dissolved proteolytic activity (Table 4). The size distribution of total activity in the pore

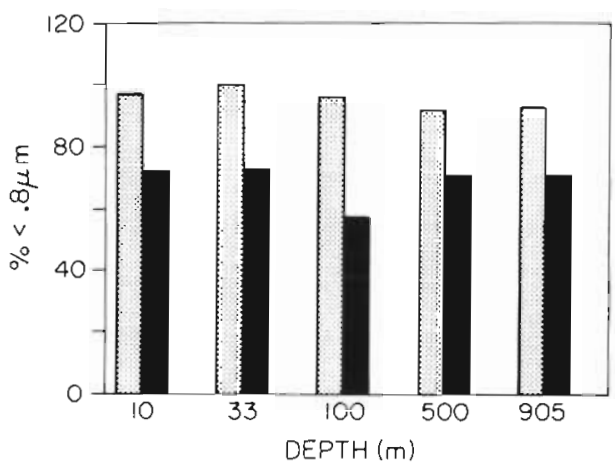

Fig. 2. Percent of cell numbers (dotted bars) and particulate proteolytic activity (solid bars) in samples taken from various depths in spring 1986 which passed a 0.8 um Nuclepore filter Particulate activity was defined as: total activity minus activity in $0.2 \mu \mathrm{m}$ filtrate waters could not be determined from our data since most bacteria and other particles would have been removed by the centrifugation used during sample preparation. In some cases there appeared to be more activity in the $<0.2 \mu \mathrm{m}$ fraction than in the unfiltered porewater, which may be due to an underestimation of the activity in the whole waters caused by blank problems (see 'Materials and Methods'). However, it is still apparent that there is a relatively large amount of nonparticle-associated activity in the sediments, especially when compared to the water column. Furthermore, this activity was either not diffusing out into the much more dilute water above, or did so too slowly to significantly enhance the dissolved activity in the overlying water.

\section{Kinetics}

Hydrolysis of LL $\beta N$ by samples collected from the SIO pier showed typical Michaelis Menten type kinetics, with saturation at about $1 \mathrm{mM}$ substrate, as had been previously reported for seawater (Somville \& Billen 1983). However, in the few cruise samples tested, LL $\beta N$ hydrolysis rates increased to a maximum at or, in the case of 2 deep water samples, below $1 \mathrm{mM} L L \beta N$ (between 0.5 and $1.0 \mathrm{mM}$ ), with decreasing rates at higher concentrations. We considered that this apparent decrease in proteolytic activity above saturating substrate concentrations might have been caused by a concurrent degradation of contaminating $\beta$-naphthylamine $(\beta N)$, which would increase in proportion to LLßN concentrations. However, we could not detect $\beta N$ degradation in pier seawater, and other explanations, such as substrate inhibition or precipitation of the substrate at higher concentrations, are equally plausible (formation of a precipitate was sometimes found to interfere with longer and/or colder incubations and may also have contributed to blank problems)

\section{Temperature dependence}

Temperature effect on rate of $L L \beta N$ hydrolysis was assessed using representative water samples from the spring cruise and SIO pier seawater Using $1 \mathrm{mM}$ $L L \beta N$ and the temperature range indicated (Table 5), $\mathrm{Q}_{10}$ values (Velocity $\left[\mathrm{T}+10^{\circ} \mathrm{C} /\right.$ / Velocity[T $\left.{ }^{\circ} \mathrm{C}\right]$ ) averaged 2.2 (range: 1.9 to 2.4), and decreased with decreasing substrate concentrations (not shown), as would be expected for most enzymes (Hochachka \& Somero 1984). There was no apparent difference between deep and surface water samples in the temperature dependence of their proteolytic activity. 


\section{Correlation analysis}

Total proteolytic activity was correlated with all bacterial parameters tested (Table 6; Spearman's rank correlation; Rafferty et al. 1985). This was true for individual profiles (data not shown) and combined profiles from the fall cruise, and for both seasons and all depths combined. The most significant correlation overall was between proteolytic activity and bacterial production.

Table 5. Temperature dependence of proteolytic activity $(1.0$ mM LLBN)

\begin{tabular}{|c|c|c|}
\hline $\begin{array}{l}\text { Depth } \\
\text { (m) }\end{array}$ & $\begin{array}{l}\text { Temp. range } \\
\text { assayed }\left({ }^{\circ} \mathrm{C}\right)\end{array}$ & $\mathrm{Q}_{10}$ \\
\hline 27 & 5-15 & 2.40 \\
\hline$[500]^{\mathrm{b}}$ & $7-15$ & 2.40 \\
\hline$[500]^{\mathrm{b}}$ & $7-15$ & 2.16 \\
\hline PSW & $8-15$ & 1.92 \\
\hline \multicolumn{3}{|c|}{$\begin{array}{l}\text { a.ll samples from Sth 305, except surface seawater from } \\
\text { SIO pier (PSW) } \\
{ }^{b} \text { Concentrated samples from } 2 \text { independent hydrocasts }\end{array}$} \\
\hline
\end{tabular}

Table 6. Spearman's rank correlations between proteolytic activity, proteolytic activity per cell and measured bacterial variables. Correlation coefficients (Spearman's rhos) shown, with values significant at $p \leq 0.001$ underlined

\begin{tabular}{|c|c|c|c|c|c|}
\hline & & 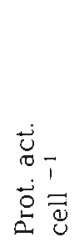 & $\begin{array}{l}\bar{I} \\
\bar{\Xi} \\
\ddot{U} \\
\mathcal{U}\end{array}$ & 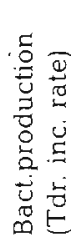 & 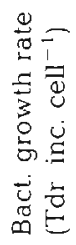 \\
\hline 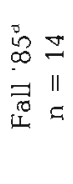 & $\begin{array}{l}\text { Total prot act. } \\
\text { Prot. act cell } \\
\text { Cells ml } \\
\text { Bact production }\end{array}$ & .838 & $\frac{805}{.383}$ & $\begin{array}{l}.942 \\
.652 \\
.904 \\
\end{array}$ & $\begin{array}{l}. \frac{922}{.820} \\
.693 \\
.877\end{array}$ \\
\hline 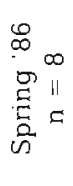 & $\begin{array}{l}\text { Total prot. act. } \\
\text { Prot. act cell } \\
\text { Cells } \mathrm{ml}^{-1} \\
\text { Bact. production }\end{array}$ & .838 & $\frac{.952}{. \overline{7} 62}$ & $\begin{array}{l}.905 \\
786 \\
.905\end{array}$ & $\begin{array}{l}.667 \\
.667 \\
.714 \\
.905\end{array}$ \\
\hline 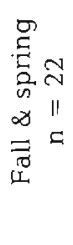 & $\begin{array}{l}\text { Total prot. act. } \\
\text { Prot. act cell } \\
\text { Cells } \mathrm{ml}^{-1} \\
\text { Bact. production } \\
\text { a Profiles } 1 \text { and } 3\end{array}$ & .832 & $\frac{.926}{.635}$ & $\frac{.947}{\frac{.778}{.923}}$ & $\frac{.900}{.828}$ \\
\hline
\end{tabular}

Total activity also correlated well with bacterial abundance ( $p \leq 0.001$ in both spring and fall). This was the strongest of the correlations tested in the spring, but of less significance than other correlations in the fall. The profiles from the fall cruise (Fig. 1) also indicated that the depth distribution pattern of total proteolytic activity did not necessarily follow that of bacterial numbers at that time. Furthermore, the average activity per bacterium varied greatly, both in spring and fall, and this variability could not be accounted for by changes in bacterial size (Fig. 3). Thus, proteolytic activity would probably correlate with bacterial biomass no better than with bacterial numbers.

Average amount of proteoly:ic activity per cell correlated best with total proteolytic activity and growth rate, both in fall and overall, indicating that where there is more activity, there is generally more activity per cell, and that cells that are growing faster tend to have more proteases or peptidases. Additional analysis of representative samples from both seasons (Fig. 3) indicated that there was no apparent relationship between proteolytic activity per cell and average cell size. This analysis also demonstrated the covariance between growth rate and proteolytic activity per cell in fall but not in spring. The

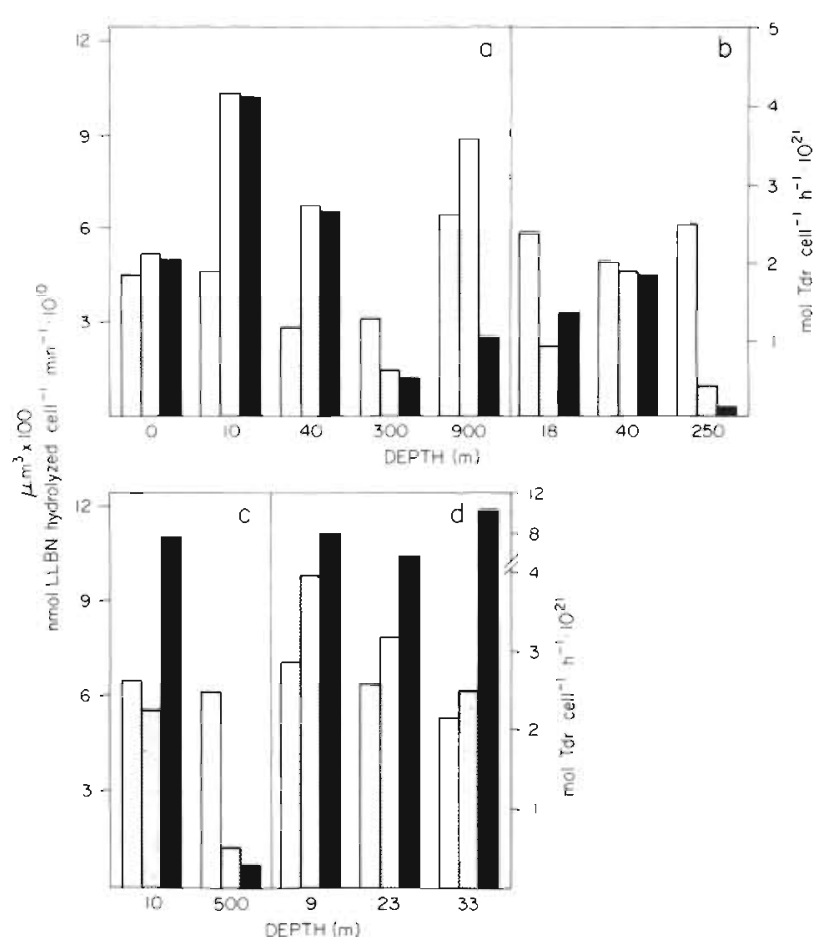

Fig. 3. Average cell volume $\left(\mu \mathrm{m}^{3}\right.$; open bars), proteolytic activity per cell (nmol LLßN hydrolyzed cell ${ }^{-1} \mathrm{~min}^{-1}$; stippled bars), and thymidine incorporation per cell (mol Tdr cell ${ }^{-1} \mathrm{~h}^{-1}$; solid bars) in various samples. (a) Stn 305, fall 1985; (b) Stn 304, fall 1985; (c) Stn 305, spring 1986; (d) Stn 303, spring 1986 
correlation between proteolytic activity per cell and growth rate was weak $(p<0.05)$ in spring, when activity per cell correlated better with bacterial production and cell numbers $(0.001<\mathrm{p}<0.05)$, in addition to total proteolytic activity $(\mathrm{p}=0.01)$.

\section{Seawater culture studies}

Seawater cultures (SWCs) were used to explore the relationships between proteolytic activity and bacterial abundance, biomass, and growth rate. These cultures are mixed populations of marine bacteria grown in unenriched, filtered seawater, but show the classical growth pattern of pure cultures. Exponential and stationary phases represented, respectively, situations where relatively few cells are growing relatively fast and where larger numbers of cells are growing slowly or not at all.

Results of 2 SWCs (Fig. 4) indicate that marine bacteria expressed more proteolytic activity when growing fast than when growing slowly or not at all (growth indicated by change in cell numbers in SWC 1 and measured as ${ }^{3} \mathrm{H}$ Tdr incorporation into DNA in SWC 2). In both cases, increases in proteolytic activity per cell could not be accounted for solely by the measured increases in cell volumes, which normally occur in SWCs (Ammerman et al. 1984, M. Brewer pers. comm.). This was true despite the fact that the ranges of proteolytic activity per cell in the 2 cultures differed greatly. In addition, proteolytic activity per cell decreased more slowly than cell size in SWC 1, but more rapidly than cell size in SWC 2. Qualitatively, changes in proteolytic activity per cell in SWC 2 were intermediate between the changes in cell sizes and growth rates, since cell growth rates in SWC 2 increased proportionately more than proteolytic activity per cell during exponential phase and dropped off more rapidly than proteolytic activity per cell in stationary phase.

\section{DISCUSSION}

In the past several years, a variety of techniques have been developed which are sensitive enough to measure protein and peptide degradation in natural waters (Hollibaugh \& Azam 1983, Hoppe 1983, Somville \& Billen 1983. Hashimoto et al. 1985). One of these techniques measures the hydrolysis of LL $\beta N$, a compound containing a peptide-like bond between an amino acid (leucine) and $\beta$-naphthylamine. Although LL $\beta N$ is not a naturally occurring compound, the use of LL $\beta N$ as substrate has the advantage of being a very sensitive and direct method. LL $\beta N$ should be hydrolyzed by aminopeptidases and non-specific proteases, and whole proteins have been shown to inhibit competitively its hydrolysis (Somville \& Billen 1983). If we assume that proteases in the ocean are fairly non-specific, so as to allow for the utilization of the wide variety of peptides which probably make up the combined hydrolyzable amino acid pool (CHAAs), then LL $\beta N$ hydrolysis rates would be a fair representation of the relative rates of hydrolysis of natural proteinaceous substrates.

Our data on LL $\beta N$ hydrolysis rates in the SMB demonstrate that rates of protein degradation vary greatly in the water column. The proteolytic activities we measured indicated that the relative amounts of proteolytic enzymes in the upper $(<100 \mathrm{~m})$ as opposed to deep waters differed by more than an order of magnitude in both spring and fall. The effect of temperature on these rates $\left(Q_{10}=2.2\right.$ for both deep and surface waters) suggests even greater differences in maximum in situ rates of proteolysis between surface waters and the colder deep waters. Indeed, turnover of proteinaceous material occurs much faster in the upper waters than in the deep waters since CHAA concentrations have, on other occasions, been found to differ by only 3 to 4 -fold (Williams 1986) in the upper and lower portions of the

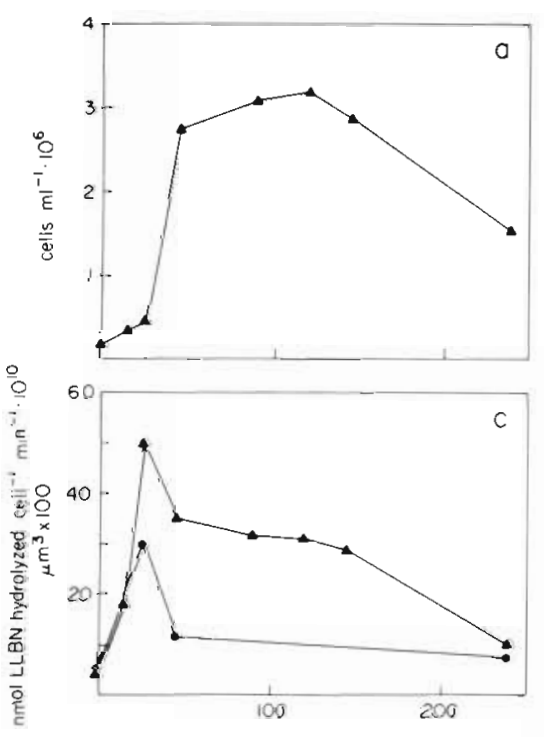

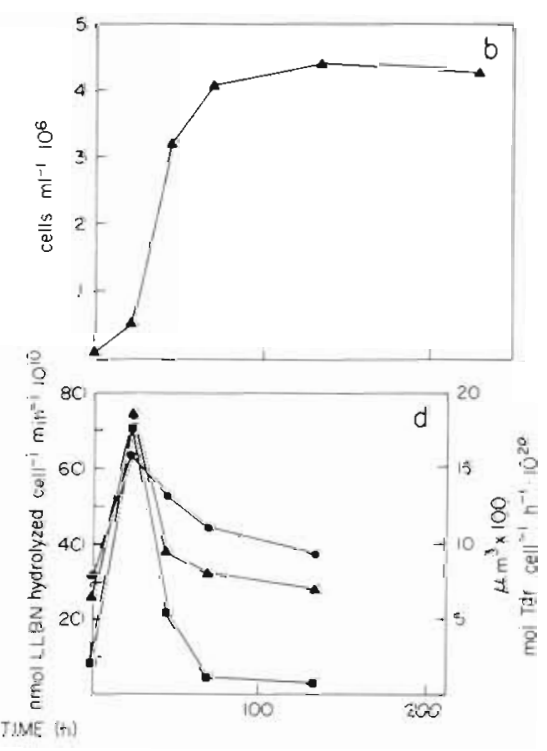

Fig. 4. Time courses of 2 seawater cultures. $(a, b)$ Changes in bacterial numbers: $(c, d)$ changes in proteolytic activity per cell (nmol LL $\beta \mathrm{N}$ hydrolyzed cell ${ }^{-1}$ $\left.\min ^{-1}\right)(4)$, average cell volume $\left(\mu \mathrm{m}^{3}\right)(\bullet)$ and bacterial growth rates (thymidine incorporation into DNA per cell, mol Tdr cell $^{-1} h^{-1}$ ) ( SWC 2 only). (a) and (c) are from SWC 1, (b) and (d) from SWC 2. Results from a third seawater culture run simultaneously with Culture 2 are not shown, but were essentially identical to those illustrated for SWC 2 
$\mathrm{SMB}$ water column. Proteolytic activity in the upper waters was also found to vary considerably with the season, in parallel with other biological parameters, but it is not known to what extent CHAA concentrations varied with season in our samples. CHAA concentrations are also not known for the sediments, but in our data set sediment porewaters had extremely high proteolytic activity relative to the water column samples.

In the water column, most of the proteolytic activity appeared to be associated with the bacteria themselves. Total activity correlated well with bacterial parameters and fractionated predominantly with particles the size of free-living bacteria $(0.2$ to $0.8 \mu \mathrm{m})$. A significant fraction of the proteolytic activity was often found in the $0.2 \mu \mathrm{m}$ filtrate, as has been reported for the waters around Tokyo (Hashimoto et al. 1985), and in an isolated occurrence in Belgian coastal waters (Somville \& Billen 1983). This dissolved activity is more likely due to the lysis of cells than to excretion of enzymes by bacteria (Vives Rago et al. 1985, A. L. Rosso unpubl.). However, autolysis of cells other than bacteria (Meyer-Reil 1981) and/or 'sloppy feeding' (Azam \& Ammerman 1984a), cannot be ruled out as additional sources of dissolved enzyme.

In comparison with the water column, there was a great deal of non-particle-associated proteolytic activity in the sediments, though the importance of this dissolved activity relative to the total sediment activity could not be determined. Others have also detected dissolved proteolytic activity in sediments (Sizemore et al. 1973, Kim \& ZoBell 1974, Meyer-Reil 1981), but the quantitative significance of the dissolved activity could not be determined from any of these studies either. Whether or not bacteria are the source of the dissolved activity in the SMB sediments could also not be determined. Excretion of enzymes could, however, be an energetically efficient way for bacteria to hydrolyze proteins in the sediments, whereas it could not be in the water column because the excreted enzymes would diffuse away from their source (Sizemore et al. 1973, Hollibaugh \& Azam 1983)

The breakdown of proteins in particles $>0.8 \mu \mathrm{m}$ diameter may also occur by a different mechanism than that used for dissolved proteins in the bulk of the water column. The proportion of the total proteolytic activity associated with such particles in the surface waters was greater than either the bacterial numbers or bacterial production associated with these particles. Bacteria on particles may have more proteolytic activity than freeliving bacteria (Hollibaugh \& Azam 1983, Vives Rego et al. 1985), colonizing bacteria may excrete proteases (Sizemore et al. 1973), or there may be other sources of particle-associated proteases besides bacteria, such as residual digestive enzymes in fecal pellets. The increased proportion of bacterial production found to be associated with these larger particles at greater depths suggests that hydrolysis of such particles may be more important for bacterial nutrition in deeper waters.

The majority of the proteolytic activity throughout the water column is, however, likely to be controlled by a number of factors related to the predominantly freeliving bacteria. Others have found that biomass or bacterial cell numbers correlate well with proteolytic activities (Hollibaugh \& Azam 1983, Fontigny et al. unpubl.), but we have found, in addition, a high correlation between proteolytic activity and bacterial production, and in some cases between proteolytic activity and bacterial growth rates. Average activity per cell in our natural samples was not related to average cell volume at either sampling time, suggesting bacterial biomass may not be an accurate indicator of proteolytic activity in all cases. Changes in activity per cell did, however, parallel changes in bacterial growth rates throughout the water column in fall, but not in spring. Hoppe (1983) has similarly found contrasting results when comparing proteolytic activity with bacterial parameters in 2 fjords: in the Kieler Fjord, activity decreased more or less regularly from the inner fjord out towards the ocean in conjunction with bacterial numbers, biomass, and production, but at certain stations within the more enclosed and eutrophic Schlei Fjord, proteolytic activity increased along with bacterial production while bacterial numbers and biomass, as well as other enzymatic activities, decreased. Thus it seems that under some conditions, possibly when bacterial growth is nitrogen limited, populations with greater proportions of highly proteolytic cells, which could make good use of the nitrogen available in proteins, would be able to grow faster. Under other environmental conditions, bacterial growth may not be as dependent upon obtaining the nitrogen or energy available in proteins, and proteolytic activity would seem a more general characteristic of bacterial abundance. However, in our SWC studies, neither growth rate nor biomass alone could account for changes in the amount of proteolytic activity expressed per bacterium, suggesting that both factors may contribute simultaneously or that other parameters not measured are involved.

The high degree of correlation between bacterial production and proteolytic activity in the natural samples is consistent with the idea of dissolved protein being an important source of nutrition for marine bacteria; where more proteinaceous material was presumably being hydrolyzed and utilized by bacteria, there was greater bacterial production. Although the role of dissolved proteins in the nutrition of marine bacteria is not known, there is evidence to suggest that bacterial growth in seawater may be nitrogen limited (Horrigan et al. 1984). Thus, CHAAs, which are far more abundant than free amino acids (Sharp 1983, Billen 1984, Williams 
1986), may be important sources of nitrogen as well as energy for marine bacteria. Protein hydrolysis would, therefore, be important to our understanding of bacterial growth as well as to our understanding of organic matter cycling in the oceans.

Acknowledgements. We thank M. Brewer and B. B. Ward for constructive criticism of the manuscript, R. Jahnke for core samples and use of his unpublished data, R. W. Eppley and B. C. Cho for use of their unpublished data, and D. B. Craven and M. A. Powell for their endless help and patience throughout this project. This work was supported by NSF grant \#OCE85-01363 to F. Azam and DOE grant \#DE-FG0585ER60037 to F. Azam and A. F. Carlucci.

\section{LITERATURE CITED}

Amano, M., Hara, S., Taga, N. (1982). Utilization of dissolved amino acids in seawater by marine bacteria. Mar. Biol. 68: $31-36$

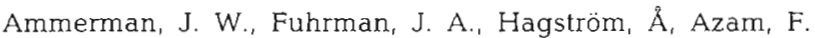
(1984). Bacterioplankton growth in seawater: I. Growth kinetics and cellular characteristics in seawater cultures. Mar. Ecol. Prog. Ser. 18: 31-39

Azam, F., Ammerman, J. W. (1984a). Cycling of organic matter by bacterioplankton in pelagic marine ecosystems: microenvironmental considerations. In: Fasham, M. J. (ed.) Flows of energy and materials in marine ecosystems. Plenum Press, New York, p. 345-360

Azam, F., Anmerman, J. W. (1984b). Mechanisms of organic matter utilization by marine bacterioplankton. In: HolmHanson, O., Bolis, L., Gilles, R. (ed.) Lecture notes on coastal and estuarine studies: marine phytoplankton and productivity. Springer-Verlag, Berlin, p. 45-54

Billen, G. (1984). Heterotrophic utilization and regeneration of nitrogen. In: Hobbie, J. E., Williams, P. J, LeB (ed.) Heterotrophic activity in the sea. Plenum Press, New York, p. 313-355

Carlucci, A. F., Eppley, R. W., Beers, J. R. (1986). Introduction to the Southern California Bight. In: Eppley, R. W. (ed.) Lecture notes on coastal and estuarine studies: plankton dynamics on the Southern California Bight. Springer-Verlag, New York, p. 1-13

Eppley, R. W., Sapienza, C., Renger, E. H. (1978). Gradients in phytoplankton stocks and nutrients off Southem California in 1974-76. Estuar. coast. mar. Sci. 7: 291--301

Fuhrman, J. A. (1981). Influence of method on the apparent size distribution of bacterioplankton cells: epifluorescence microscopy compared to scanning electron microscopy. Mar. Ecol. Prog. Ser. 5: 103-106

Fuhrman, J. A., Azam, F. (1982). Thymidine incorporation as a measure of heterotrophic bacterioplankton production in marine surface waters: evaluation and field results. Mar Biol. 66: 109-120

Hashimoto, S., Fujiwara, K., Fuwa, K., Saino, T (1985). Distribution and characteristics of carboxypeptidas activity in pond, river, and seawaters in the vicinity of Tokyo. Limnol. Oceanogr 30:631-645
Hobbie, J. E., Daley, R. J., Jasper, S. (1977). Use of Nuclepore filters tor counting bacteria by fluorescence microscopy. Appl. environ. Microbiol. 33: 1225-1228

Hochachka, P. W., Somero, G. N. (1984). Temperature adaptation. In: Biochenical adaptation. Princeton Univ. Press Princeton, New Jersey, p. 355-450

Hollibaugh, J. T., Azam, F. (1983). Microbial degradation of dissolved proteins in seawater. Limnol. Oceanogr. 28: $1104-1116$

Hoppe, H.-G. (1983). Significance of exoenzymatic activities in the ecology of brakish water: measurements by means of methylumbelliferyl-substrates. Mar. Ecol. Prog. Ser. 11: 299-308

Horrigan, S. G., Hagström, Å., Azam, F., Koike, I. (1984) Bacterioplankton growth in seawater may be nitrogen limited. Eos 65: 921

Jahnke, R. A., Emerson, S. R., Cochran, J. K., Hirschberg, D. J. (1986). Final scale distributions of porosity and particulate excess ${ }^{210} \mathrm{~Pb}$, organic carbon and $\mathrm{CaCO}_{3}$ in surface sediments of the deep equatorial Pacific. Earth Planet. Sci. Lett. 77: 59-69

Kim, J., ZoBell, C. E. (1974). Occurence and activities of cellfree enzymes in oceanic environments. In: Colwell, R. R. Morita, R. Y. (ed.) Effect of the ocean environment on microbial activities. University Park Press, London, $p$. 368-385

Law, B. A. (1980). Transport and utilization of proteins by bacteria. In: Payne, J. W. (ed.) Microorganisms and nitrogen sources. John Wiley \& Sons, Chichester, p. 381-409

Meyer-Reil, L.-A. (1981). Enzymatic decomposition of proteins and carbohydrates in marine sediments: methodology and field observations during spring. Kieler Meeresforsch., Sonderh. 5: 311-317

Rafferty, J., Norling, R., McMath, C., Tamaru, R., Morganstein, D. (1985). StatWorks: statistics with graphics for the Macintosh. Data Metrics, Inc., Hayden and Son, Inc., Philadelphia

Sharp, J. H. (1983). The distributions of inorganic nitrogen and dissolved and particulate organic nitrogen in the sea. In: Carpenter, E. J., Capone, D. G. (ed.) Nitrogen in the marine environment. Academic Press, New York, p. 1-35

Sizemore, R. K., Stevenson, H. L., Hebeler, B. H. (1974). Distribution and activity of proteolytic bacteria in estuarine sediments. In: Stevenson, L. H., Colwell, R. R. (ed.) Estuarine microbial ecology. Univ. South Carolina Press, Columbia, p. 133-143

Somville, M., Billen, G. (1983). A method for determining exoproteolytic activity in natural waters. Limnol. Oceanogr. 28: 190-193

Vives Rego, J., Billen, G., Fontigny, A., Somville, M. (1985). Free and attached proteolytic activity in water environments Mar Ecol. Prog. Ser 21: 245-249

Williams, P. M. (1986). Chemistry of the dissolved and particulate phases in the water column. In: Eppley, R. W. (ed.) Lecture notes on coastal and estuarine studies: plankton dynamics on the Southern California Bight. Springer-Verlag, New York, p. 53-84

Wheeler, P. A., Kirchman, D. L. (1986). Utilization of inorganic and organic nitrogen by bacteria in marine systems. Limnol. Oceanogr. 31: 998-1009 